\title{
Enterographa serusiauxii, a new foliicolous lichen species from Guadeloupe
}

\author{
Elise Lebreton ${ }^{1 *} \&$ Andre Aptroot ${ }^{2}$
}

\section{Article info}

Received: 30 Sept. 2019

Revision received: 6 Nov. 2019

Accepted: 4 Dec. 2019

Published: 2 Jun. 2020

Associate Editor

Bernard Goffinet

\begin{abstract}
The new species Enterographa serusiauxii (crustose Roccellaceae, lichenized Ascomycetes) is described from Guadeloupe. It grows abundantly on leaves of Garcinia humilis and Calophyllum calaba in coastal vegetation. It was already collected in the previous century by Le Gallo, but these specimens were only identified recently by us. In 2019 it was recollected in the type locality by the first author.
\end{abstract}

Key words: Guadeloupe, Lesser Antilles, foliicolous, Roccellaceae, Enterographa

\section{Introduction}

Before 1950, foliicolous lichens in Guadeloupe were almost unknown. Santesson (1952) cited eight additional species from Guadeloupe, based on samples collected by P. and V. Allorge in 1936. Vivant collected many lichens in Guadeloupe, bringing the number of foliicolous lichens to 66 species (Vězda \& Vivant 1992), including two newly described species (Vězda 1994). Sérusiaux (1998) described four new species of Gyalideopsis species from Guadeloupe and added 22 taxa not previously reported from Guadeloupe. Lücking (2008) mentions numerous records from Guadeloupe. Surveys carried out in 2007 and 2009 by Bricaud (2009) increased the number of foliicolous taxa in Guadeloupe to 165 .

From 1951 to 1970, the priest C. Le Gallo collected many foliicolous lichens and gave them to the National Museum of Natural History (MNHN, Paris). In 1953, a part of the collection was given to Santesson, who identified 29 species in it without publishing them (Le Gallo 1972). The collection was not further studied until now, and the first outcome of our identification is the report of one new species. The final results of the examination of this collection will be the subject of a future paper, but here we describe the new species found in it.

Le Gallo collected a sample of Enterographa that remained unnamed. While the species appears abundant on leaves of Garcinia humilis and Calophyllum calaba in

\footnotetext{
${ }^{1}$ UMS PatriNat, Laboratoire de Bryologie. Museum National d'Histoire Naturelle (MNHN), 12 rue Buffon, 75005 Paris, France

${ }^{2}$ Laboratório de Botânica / Liquenologia, Instituto de Biociências, Universidade Federal de Mato Grosso do Sul, Avenida Costa e Silva s/n, Bairro Universitário, CEP 79070-900, Campo Grande, Mato Grosso do Sul, Brazil

* Corresponding author e-mail: eliselebreton@yahoo.fr
}

coastal vegetation ( $<10 \mathrm{~m}$ alt.), it was not recollected to our knowledge until 2019, when the first author visited the original locality. The species is described below.

\section{Material and methods}

Identification and descriptive work employed an Olympus SZX7 stereomicroscope and an Olympus BX50 compound microscope with interference contrast, connected to a Nikon Coolpix digital camera. Sections were mounted in tap water, in which also all measurements were taken. IKI reactions were seen by adding commercial undiluted Lugol (Merck 9261). The chemistry of most specimens was investigated by thin-layer chromatography (TLC) using solvent A (Orange et al. 2001).

\section{Results}

Enterographa serusiauxii Lebreton \& Aptroot, sp. nov.

(Fig. 1)

Mycobank MB 833296

Diagnosis: foliicolous Enterographa with verrucose thallus and 7-9-septate ascospores, (25-)27-29 × 2.5-3.5 $\mu \mathrm{m}$.

Type: Guadeloupe, Littoral de Robin municipality of Trois Rivières, $15^{\circ} 58^{\prime} 1.596^{\prime \prime} \mathrm{N}, 61^{\circ} 39^{\prime} 10.943^{\prime \prime} \mathrm{W}$, alt. $7 \mathrm{~m}$, leg. E. Lebreton \& R. Poncet, 7 March 2019, on living leaves (Garcinia humilis) in coastal forest, (PC0712097 - holotype!, ABL - isotype!).

Description. Thallus crustose, foliicolous, very pale cream to off-white, to $\sim 9 \mathrm{~mm}$ in diam. and $\sim 0.1 \mathrm{~mm}$ thick, very uneven, verruculose, with verruculae $\sim 0.1 \mathrm{~mm}$ diam., up to $0.2 \mathrm{~mm}$ thick in places with apothecia, in section with numerous hyaline crystals; without prothallus 

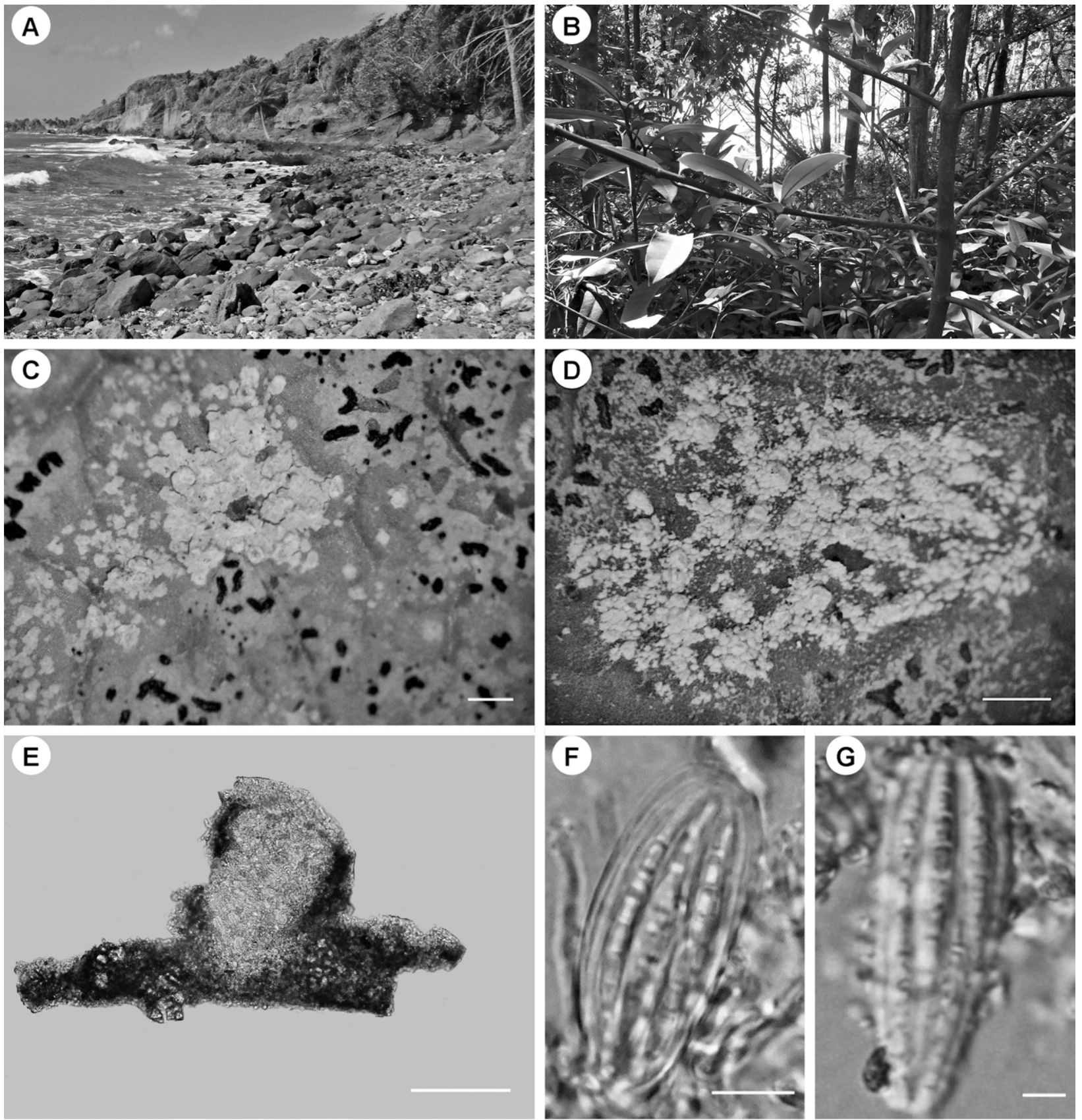

Figure 1. Enterographa serusiauxii: A-B - Littoral de Robin, location of the holotype; C - holotype, PC, thalli with apothecia collected in 2019; D - isotype, PC, thalli with apothecia collected in 1958 by Le Gallo; $\mathrm{E}$ - section showing apothecium; F - holotype, asci with ascospores; $\mathrm{G}$ - isotype asci and ascospores (from Le Gallo collection). Scales: $\mathrm{C}-\mathrm{D}=1 \mathrm{~mm} ; \mathrm{E}=0.1 \mathrm{~mm} ; \mathrm{F}-\mathrm{G}=5 \mu \mathrm{m}$. The color version will be available online

but often with small areas without thallus between verruculae. Photobiont Trentepohlia, cells elongate in outline, yellowish green to orange. Ascomata apothecia, immersed in thallus, oval to irregularly slit-like, $\sim 0.15$ $\times 0.2-0.4 \mathrm{~mm}$; disc pale brown, flat to concave; margins of thallus structure and colour, $\sim 0.1 \mathrm{~mm}$ wide. Hymenium hyaline, $\sim 50 \mu \mathrm{m}$ high; epihymenium, excipulum and hypothecium hyaline. Paraphyses anastomosing. Asci ellipsoidal, $\sim 45 \times 15 \mu \mathrm{m}$. Ascospores hyaline, 8 per ascus, slender clavate, slightly curved, 7-9-septate, (25-)27-29 $\times 2.5-3.5 \mu \mathrm{m}$, walls thickened, with $1 \mu \mathrm{m}$ thick gelatinous sheath. Pycnidia not observed.

Chemistry. Medulla K-, P-, C+ red, UV-. TLC: gyrophoric acid.
Etymology. This new species is named in honour of Emmanuël Sérusiaux, who introduced both of us to the study of foliicolous lichens, and who has a profound interest in foliicolous lichens and in the lichen flora of Guadeloupe.

Notes. The internal structures, especially the curved ascospores with thick walls, are in accordance with the genus Enterographa sensu Sparrius (2004). The new species differs from all species treated by Sparrius (2004) by its verrucose thallus, the long ascospores and the chemistry. The recently described foliicolous species $E$. oregonensis (Sparrius \& Björk 2008) differs by the C-negative thallus. In the recent world key to species of Enterographa (Seavey \& Seavey 2014) the new species would key out close to E. oregonensis. 
Distribution and ecology. Known only from Guadeloupe. On living leaves of Garcinia humilis and Calophyllum cal$a b a$ in coastal vegetation. The species is locally abundant (as can be seen from the many specimens cited) and often accompanied by numerous individuals of Opegrapha sp.

Additional specimens examined. Same details as type; PC0712066, PC0712067, PC0712068, PC0712069, PC0712070, PC0712071, PC0712072, PC0712073, PC0712074, PC0712075, PC0712076, PC0712077, PC0712078, PC0712079, PC0712080, PC0712081, PC0712098 \& PC0712099 (all PC - paratypes!); same locality as type, 17 April 1958, C. Le Gallo PC0712077, PC0712078 (all PC - topotypes!); Grande Anse (Trois Rivières), $15^{\circ} 58^{\prime} 1.596^{\prime \prime} \mathrm{N}, 61^{\circ} 39^{\prime} 10.943^{\prime \prime} \mathrm{W}, 20$ November 1961, C. Le Gallo; PC0712072, PC0712073, PC0712074, PC0712075, PC0712076 (all PC!); Embouchure de la rivière Sarcelle (Petit Bourg/Goyave), 16 9 9'40.464"N, 6134'59.195"W, 13 November 1961, C. Le Gallo; PC0712079, PC0712080, PC0712081 PC0712066, PC0712067, PC0712068, PC0712069, PC0712070, PC0712071 (all PC!); Anse à Sable, $16^{\circ} 8^{\prime} 55.032^{\prime \prime} \mathrm{N}$, $61^{\circ} 46^{\prime} 27.155^{\prime \prime} \mathrm{W}, 9$ March 2019, E. Lebreton \& R. Poncet; PC0712096 (PC!).

\section{Acknowledgements}

This study was financed by Direction générale déléguée à la recherche, à l'expertise, à la valorisation et à l'enseignement-formation (DGD-REVE) - Museum National d'Histoire Naturelle (MNHN) France. This species was discovered during a master's internship supervised by Sébastien Leblond and Rémy Poncet.

\section{References}

Bricaud, O. 2009. Prospection de la végétation lichénique du Parc National de la Guadeloupe et de sa zone périphérique: résultats de la prospection 2009 des groupements foliicoles phaseIII, 12p. http:// documentation.guadeloupe-parcnational.fr/IMG/pdf/2009_prospection_vegetation_lichenique_png_et_zone_peripherique-resultats_ prospection_2009_phase3.pdf

Le Gallo, C. 1972. Lichens de Guadeloupe. Manuscrit inédit du MNHN.

Lücking, R. 2008. Foliicolous lichenized fungi. Flora Neotropica Monograph 103: 1-866.

Orange, A., James, P. W. \& White, F. J. 2001. Microchemical Methods for the Identification of Lichens. British Lichen Society, London.

Santesson, R. 1952. Foliicolous lichens I. A revision of the taxonomy of the obligately foliicolous, lichenized fungi. Symbolae Botanicae Upsalienses 12: 1-590.

Seavey, F. \& Seavey, J. 2014. New additions to the lichen genus Enterographa (Roccellaceae) from Everglades National Park including an updated world key. Lichenologist 46: 83-93.

Sérusiaux, E. 1998. Notes on the Gomphillaceae (lichens) from Guadeloupe (West Indies), with four new species of Gyalideopsis. Nova Hedwigia 67: 381-402.

Sparrius, L. B. 2004. A Monograph of Enterographa and Sclerophyton. Bibliotheca Lichenologica 89: 1-141.

Sparrius, L. B. \& Björk, C. R. 2008. Enterographa oregonensis (Roccellaceae), a new foliicolous species from the northwest coast of North America. The Bryologist 111: 487-489.

Vězda, A. 1994. Neue foliicole Flechten II. Nova Hedwigia 58: 123-143.

Vězda, A. \& Vivant, J. 1992. Lichens épiphylles de la Guadeloupe. Bulletin de la Société Botanique de France 139: 275-281. 